\title{
Effects of Meteorological and Site Parameters on the Health Status of Beech (Fagus sylvatica L.) Forests in Hungary
}

\author{
Gergely JANIK ${ }^{\mathrm{a}^{*}}-$ Zoltán PÖDÖR $^{\mathrm{b}}-$ András KOLTAY $^{\mathrm{c}}-$ Anikó HIRKA $^{\mathrm{c}}-$ \\ János JuHÁSZ ${ }^{\mathfrak{c}}-$ Gyula KOVÁCS $^{\mathrm{c}}-$ György CSÓKA $^{\mathrm{c}}$ \\ ${ }^{a}$ KEFAG Kiskunság Forestry and Woodworking Company, Kecskemét, Hungary \\ ${ }^{\mathrm{b}}$ Simonyi Károly Faculty of Engineering, Wood Sciences and Applied Arts, University of Sopron, Hungary \\ ${ }^{\mathrm{c}}$ Forest Research Institute, National Agricultural Research and Innovation Centre, Sárvár, Hungary
}

\begin{abstract}
The influence of meteorological parameters on the health status of beech (Fagus sylvatica L.) was analyzed using long term datasets (1989-2010) collected in 15 sample plots located in Hungary's main beech regions. Leaf loss values were correlated with different meteorological parameters as explanatory variables. Analysis was performed by the CReMIT (Cyclic Reverse Moving Intervals Techniques) method. Weather, stand, and site parameters were also examined with PCA for comparison. Leaf loss levels showed stronger correlations with maximum monthly temperatures than with monthly precipitation sums. The monthly number of summer days and monthly number of hot days displayed a similar correlation to leaf loss as the maximum monthly temperature did. The correlations were regularly stronger and more frequent on more arid sites where the climate is less favorable for beech. Temperature affected leaf loss more than precipitation did. Our results show that beech forests may suffer heavy damage if climate change continues as projected.
\end{abstract}

beech /Fagus sylvatica L. / leaf loss / climate change / CReMIT / Hungary

Kivonat - Meteorológiai és egyes termőhelyi tényezők hatása a bükk (Fagus sylvatica L.) egészségi állapotára Magyarországon. A meteorológiai tényezők bükkösökre gyakorolt hatásait 15 mintaterületen gyüjtött hosszútávú (1989-2000) adatsorokon vizsgáltuk. A lombvesztés értékét különböző meteorológiai tényezőkkel korreláltattuk, a CReMIT (Cyclic Reverse Moving Intervals Techniques) mozgó időablakos módszer segítségével. Ezután az időjárási, termőhelyi és erdőállományjellemzőket is bevonva PCA analízist is végrehajtottunk. A lombvesztés erősebb kapcsolatot mutatott a havi maximum hőmérséklettel, mint a havi csapadék-összeggel. A havi nyári napok és hőségnapok összegei a maximum-hőmérséklethez hasonló összefüggéseket mutattak. A korrelációk erőssége nagyobb volt a szárazabb klímájú, bükknek kevésbé alkalmas mintaterületeken. Eredményeink alátámasztják, hogy a jövőben a bükkösök súlyos károknak lehetnek kitéve, ha a klímaváltozás az elörejelzett forgatókönyvek szerint alakul majd.

bükk / Fagus sylvatica L. / lombvesztés / klímaváltozás / CReMIT / Magyarország

\footnotetext{
`Corresponding author: janikg@kefag.hu; H-6000 KECSKEMÉT, József A. u. 2, Hungary
} 


\section{INTRODUCTION}

Although the ratio of European beech (Fagus sylvatica L.) forests is relatively low in Hungary $(112,603$ ha; $6.0 \%$ of total forested area - NFK 2020), the species still possesses ecological and economic importance. Hungarian beech forests are situated on low to mid-mountain elevations, and on extrazonal occurrences in lower, hilly areas. Due to its distinct climatic needs, beech is considered a forest-climate indicator species in Hungary. Optimal montane/submontane sites with preferable climate for beech have a restricted extent in Hungary; hence, beech forests often grow in suboptimal sites.

Beech has significant precipitation needs and weak drought tolerance (Arend et al. 2016), which makes it vulnerable to climate change (Geßler et al. 2007). This is especially true in conditions and sites where beech forests thrive in Hungary today. Nonetheless, climate change appears to have the opposite effect in other north-eastern European provenances where suitable areas for beech are expanding (Augustaitis et al. 2015).

Climate change scenarios project worsening conditions for beech forests in Southern and Eastern Europe, particularly in the Carpathian Basin (Berki et al. 2007). Some researchers suggest beech may even disappear from Hungary altogether in the next century (Mátyás et al. 2010, Führer et al. 2011). Central and Southern European beech stands have suffered incremental reduction during drought and warm years since 1980 (Jump et al. 2006, Zimmermann et al. 2015, Giagli et al. 2016). A reduction in suitable habitat for beech due to climate change is also projected for the Iberian Peninsula (del Río et al. 2018).

Hungarian forests already face direct or indirect damage related to extreme weather conditions, particularly drought damage (Csóka et al. 2009, Lakatos - Molnár 2009, Rasztovits et al. 2014, Janik et al. 2016). In Hungary, beech is close to its xeric limits, which makes it more susceptible to climate change.

As in many other European countries, severe beech declines were recorded at several locations in Hungary in the late 1980s. This the FRI (Forest Research Institute) to launch the beech health monitoring plot network in 1989 (Koltay 2004). The initiative was based on the experiences of the ICP-Forests network (Michel - Siedling 2014), and its aim was to closely monitor the health trends of Hungarian beech stands and, subsequently, analyze the collected data. In this paper we processed the dataset on beech monitoring plots, and used statistical methods to identify correlations between meteorological, forest site, forest stand, and leaf-loss parameters.

Our starting hypothesis predicted direct positive correlations between temperature-related parameters and leaf loss, and negative correlations between precipitation and leaf loss. We also expected delayed and/or cumulative effects of weather from previous years.

\section{MATERIALS AND METHODS}

\subsection{Location and main parameters of the sample plots}

Altogether, 32 beech monitoring plots have been established in Hungary since 1989. Individual sample trees were marked and numbered on the monitoring plots. The stands in which the plots are located were managed by state forest companies, according to normal management plans. All the plots were established with 100 sample trees; over time, the number of trees gradually decreased due to mortality, intermediate cutting, etc. In our present analysis, we selected 15 plots that fulfilled the criteria listed below:

- The time series was at least 15 years in duration,

- The number of sample trees in 2010 was at least 50,

- The decrease of the number of sample trees during the examined period did not exceed $30 \%$. 


\subsection{Site and stand parameters}

The ages of the monitored stands varies between 64 and 135 years. Table 1 provides other basic information about the monitored stands. The sample trees were surveyed once a year, in early September. NARIC FRI researchers completed the assessments. The visual survey was executed according to ICP methodology, and the surveyors regularly participated in international calibration workshop events (ICP Forests.net). For this study, we used the assessed leaf-loss values of the sample trees within $5 \%$ accuracy, but we scored several other parameters as well. Leaf loss is an important health indicator, and it is also comparable to other results. Only sample trees in Kraft classes 1 (outstanding/dominant) and 2 (codominant) (Kraft 1884) were included in the analysis since the trees in other social classes are too strongly influenced by competition for light.

Forest stand data involving our plots were obtained from the "Hungarian forest inventory", from the National Land Center, Department of Forestry. This database contains detailed information (including site and stand parameters) about the location of the monitoring plots in the forest compartments.

Table 1. Basic data about the 15 selected monitoring plots included in the study

\begin{tabular}{lcccrrr}
\hline $\begin{array}{l}\text { Forest } \\
\text { subcompartment }\end{array}$ & Coordinates & $\begin{array}{c}\text { First } \\
\text { year }\end{array}$ & $\begin{array}{c}\text { N (pcs) } \\
\text { (first year) }\end{array}$ & $\begin{array}{c}\text { N (pcs) } \\
(2010)\end{array}$ & $\begin{array}{c}\text { Age } \\
(2010)\end{array}$ & $\begin{array}{c}\text { Altitude } \\
(\mathrm{m})\end{array}$ \\
\hline Bőszénfa 12E & N46 15.727 E17 47.470 & 1992 & 100 & 98 & 128 & 300 \\
Felsőtárkány 140D & N48 02.394 E20 28.986 & 1994 & 100 & 98 & 101 & 600 \\
Felsőtárkány 55A & N48 01.515 E20 24.938 & 1994 & 100 & 99 & 95 & 700 \\
Füzér 86F & N48 34.248 E21 25.785 & 1992 & 97 & 81 & 86 & 700 \\
Füzér 86G & N48 34.123 E21 25.707 & 1992 & 99 & 80 & 81 & 700 \\
Gyöngyössolymos 41B & N47 52.918 E19 57.480 & 1992 & 100 & 98 & 108 & 700 \\
Kislőd 4B & N47 11.512 E17 38.402 & 1996 & 90 & 61 & 117 & 500 \\
Köszeg 43H & N47 22.103 E16 27.902 & 1992 & 76 & 64 & 133 & 800 \\
Nagyhuta 10C & N48 28.157 E21 25.580 & 1995 & 89 & 66 & 89 & 400 \\
Orfü 21B & N46 07.610 E18 10.292 & 1992 & 69 & 62 & 62 & 500 \\
Répáshuta 11C & N48 03.288 E20 32.060 & 1994 & 100 & 100 & 83 & 700 \\
Répáshuta 12G & N48 03.135 E20 32.290 & 1994 & 99 & 97 & 78 & 800 \\
Szentpéterfölde 20A & N46 36.055 E16 44.973 & 1989 & 68 & 42 & 119 & 300 \\
Ugod 31A & N47 17.534 E17 39.765 & 1992 & 120 & 84 & 101 & 500 \\
Zselickislak 8E & N46 15.617 E17 48.380 & 1995 & 100 & 99 & 126 & 400 \\
\hline
\end{tabular}

\subsection{Meteorological parameters}

Data was provided by the Hungarian Meteorological Service as a $10 \mathrm{~km} \mathrm{x} 10 \mathrm{~km}$ grid interpolated data set from standard weather station measurements by the MISH method (Szentimrey et al. 2005). We used the following monthly weather parameters from the data series: maximum monthly temperature; monthly precipitation sum; monthly number of hot days, monthly number of summer days. We chose monthly maximum temperature instead of average temperature because extreme weather events are generally more damaging to tree health. Defined meteorologically, hot days are those in which the maximum daily temperature reaches/exceeds $30^{\circ} \mathrm{C}$. Summer days are those in which the daily maximum temperature reaches/exceeds $25^{\circ} \mathrm{C}$. The meteorological dataset was available between 1961 and 2010. 


\subsection{Statistics}

Leaf loss data collected in a long-term monitoring network was correlated with different meteorological indices using CReMIT (Cyclic Reverse Moving Intervals Techniques). This is a special moving-window based method implementing moving averages and moving interval techniques (Pödör et al. 2014). The method makes it possible to systematically increase the number of used dependent or independent variables by creating new, derived time series from the basic dataset in a systematic way. Next, linear regression was used to examine the relationships between the derived meteorological parameters as independent variables, and the health status (indicated by leaf loss) as dependent variables. The significance of the results was examined by Student's t-test. To see the effects of the two previous years' weather on forest health, we examined correlations dating back 36 months. In our CReMIT analysis, the time windows did not extend beyond five months. We examined the year of the leaf loss assessment, the previous year's damage, and the leaf loss assessments from two years ago.

With temperature, precipitation, and number of summer days as parameters, we chose May, June, July, August, and September as the time windows for the three examined years. We omitted winter precipitation amounts since we decided to present results that were comparable to all weather indices.

Only the time windows from June to September were feasible for the number of hot days; thus, the length of the input time series was not exactly even. Nevertheless, through our selection of method and sample plots, we endeavored to ensure the differences would not significantly impact the results.

Forest health data was correlated with all of the derived meteorological parameters. This data was available for all the sample trees, so it was possible to stratify the results into Kraftclasses ( 1 - predominant, 2 - dominant, 3 - codominant and partially dominated, 4 - overtopped) (Kraft 1884, in Assmann 1968).

The CReMIT method created all of the continuous time series from the previous three years with the above-mentioned different window sizes ranging from one to five months.

Once the CReMIT results were achieved, the sample plots were examined according to forest site, meteorological, and stand parameters to determine if these results were similar to the CReMIT results. Principal Component Analysis (PCA) was chosen to perform this examination, mainly because the method can also be used if the parameters are not (or not fully) independent (Pearson 1901). Forest site parameters were included: in the case of forest soil, topsoil layer thickness and slope are crucial as both affect soil water dynamics. Exposure $(0=$ north slope; $180=$ south slope) and altitude define the mesoclimate.

Forest stand parameters were also used in PCA: species mixture, canopy closure, and social position (Kraft classes). Stem diameter and stand height can be complex variables due to site conditions; hence, these variables were excluded from our examinations. Table 3 contains the 14 examined environmental parameters.

Basic database management was performed with Libreoffice and Microsoft Office software. We also used R software environment and PAST v.2.17c (Hammer et al. 2001) software for statistical analysis.

\section{RESULTS}

The significant CReMIT results were rather diverse. On some occasions, neighbouring sample plots with extremely similar site conditions (and with the same interpolated meteorological datasets) surprisingly exhibited different responses. Only results with 90, 95, and 99\% significance levels of individual time windows were summarized in Table 2. 
Positive correlations were expected between "maximum monthly temperature" and leaf loss. Four plots gave consistently strong relationships; as a result, the expected correlations appeared. Unexpected negative correlation values emerged for plots located at higher elevations. These results occurred sporadically in six plots, but with one plot (Orfü 21B), the negative correlation was remarkable between the given year's leaf loss and also with the temperature values from two years prior. In Kraft class 2, the results were usually similar, with the exception of the Kislöd plot.

As expected, "summer days" gave results similar to "maximum monthly temperature". Although the number of plots with significant correlations were lower, the significance levels were usually stronger. In five plots, unexpected negative results occurred, which were similar to the maximum temperature results.

The number of "hot days" were obviously fewer than the number of "summer days", but the results were similar. The significant correlations were even stronger, but fewer in number. Negative correlation values occurred only in one plot, in two time windows, in the Kraft class 2.

In the case of "monthly precipitation sum", negative correlation values were presumed. The expected negative correlations occurred in eight plots; five of these had remarkably strong significant correlations. Unexpectedly, positive correlations occurred in five plots. Orfü 21B had a remarkable and unexpected correlation with the values from two years before the actual leaf loss values. The Kraft 2 class also shows similar but weaker correlations. The main results of the CReMIT analysis are summarized in Table 2.

Table 2. Evaluation of the CReMIT results by scoring the strength according to the frequency of significant (above 90\%) time windows $(1,2,3)$ and direction ("-" = negative correlation; "+"= positive correlation) of correlations between leaf loss and weather parameters in a given year $(0)$ and the previous two years $(-1 ;-2)$

\begin{tabular}{lrrrrrrrrrrrrr}
\hline Parameter & $\begin{array}{c}\text { Maximum } \\
\text { monthly } \\
\text { temperature }\end{array}$ & \multicolumn{1}{c}{$\begin{array}{c}\text { Monthly } \\
\text { precipitation } \\
\text { sum }\end{array}$} & Summer days & & Hot days \\
\hline Location/Year & $\mathbf{0}$ & $\mathbf{- 1}$ & $\mathbf{- 2}$ & $\mathbf{0}$ & $-\mathbf{- 1}$ & $\mathbf{- 2}$ & $\mathbf{0}$ & $\mathbf{- 1}$ & $\mathbf{- 2}$ & $\mathbf{0}$ & $\mathbf{- 1}$ & $\mathbf{- 2}$ \\
\hline Böszénfa 12E & 3 & 0 & 0 & -2 & 0 & 0 & 3 & 0 & 0 & 3 & 0 & 0 \\
Felsőtárkány 140D & 0 & 0 & 2 & 0 & 0 & 0 & -1 & 0 & 1 & 0 & 0 & 0 \\
Felsötárkány 55A & 0 & 0 & 0 & 0 & 0 & 0 & 0 & 0 & 1 & 0 & 0 & 0 \\
Füzér 86F & 2 & 0 & 0 & -3 & 0 & -1 & 3 & 0 & 0 & 0 & 0 & 0 \\
Füzér 86G & 2 & 0 & 0 & -2 & 0 & -2 & 3 & 0 & 0 & 0 & 0 & 0 \\
Gyöngyössolymos 41B & 0 & 0 & 0 & 0 & -1 & 0 & 0 & 0 & 0 & 0 & 2 & 0 \\
Kislöd 4B & 2 & 1 & 0 & -2 & 0 & 0 & 2 & 1 & 0 & 3 & 1 & 0 \\
Köszeg 43H & 1 & 0 & -1 & 0 & 0 & 0 & 2 & 0 & 0 & 3 & 0 & 0 \\
Nagyhuta 10C & -1 & -2 & -1 & -2 & -2 & 0 & -2 & -2 & 0 & 0 & 0 & -1 \\
Orfü 21B & 3 & 0 & -2 & 0 & 0 & 2 & 3 & 0 & -1 & 3 & 0 & 0 \\
Répáshuta 11C & 0 & -1 & 0 & 0 & 2 & 0 & 0 & 0 & 0 & 1 & 0 & 0 \\
Répáshuta 12G & 0 & -1 & 0 & 0 & 1 & 0 & 0 & 0 & 0 & 3 & 0 & 0 \\
Szentpéterfölde 20A & 1 & 1 & -1 & 0 & 1 & 1 & 0 & 0 & -1 & 1 & 1 & 0 \\
Ugod 31A & 0 & 0 & 3 & 2 & 1 & 0 & 0 & -1 & 3 & 0 & 0 & 1 \\
Zselickislak 8E & 3 & 0 & 0 & -2 & 0 & 0 & 3 & 1 & 0 & 3 & 0 & 0 \\
\hline
\end{tabular}

Furthermore, CReMIT results (based on leaf-loss data series) were compared with forest site data collected via PCA analysis, which was performed in 15 (meteorological, sitedependent, and stand-dependent parameters all together) variables. This resulted in four new variables (4 Axes) that together account for $85 \%$ of the variation in forest site variables of the 
sample plots (Table 3). Meteorological parameters were represented in the PCA analysis by their averages for all sample plots and for the whole examination period. Axis 1 is strongly positively correlated with the topsoil layer thickness and temperature variables, and negatively correlated with altitude. This relationship is obvious since average temperature normally increases as altitude decreases. Similarly, on lower altitudes, topsoil layers are usually thicker. The second component (Axis 2) is negatively correlated with slope, crown closure, and the proportion of Kraft class 1 and 2; it is also positively correlated with precipitation. As can be observed in the variance values of the components, temperature, and topsoil layer thickness are the main parameters. It is also clear that temperature is more relevant than precipitation sum. These support the results derived from time series analysis (CReMIT). Similar to weather, temperature has the most influence on health status at the long term level.

The third component (Axis 3) is determined by mixing ratio, and the fourth (Axis 4) contains exposure/facing and the age of trees. Only the mixing ratio determines the third component.

Table 3. Eigenvalues, proportion of variance and environmental variable loadings for the first 4 principal components in PCA

\begin{tabular}{lrrrr}
\hline \multicolumn{1}{c}{ Axes } & Axis 1 & Axis 2 & Axis 3 & Axis 4 \\
\hline Statistical parameters & & & & \\
\hline Eigenvalue & \multicolumn{1}{c}{6.0} & \multicolumn{1}{c}{2.6} & 1.8 & \multicolumn{1}{c}{1.4} \\
Explained variance & $43.0 \%$ & $18.9 \%$ & $13.0 \%$ & $10.2 \%$ \\
Cumulated variance & $43.0 \%$ & $61.9 \%$ & $74.9 \%$ & $85.1 \%$ \\
\hline Environmental variables & & & & \\
\hline Altitude & $\mathbf{- 0 . 8 0 9}$ & -0.070 & 0.264 & 0.161 \\
Exposure/Facing & 0.324 & 0.210 & -0.510 & $-\mathbf{0 . 5 1 6}$ \\
Slope & -0.441 & $\mathbf{- 0 . 5 3 9}$ & -0.447 & 0.460 \\
Topsoil layer thickness & $\mathbf{0 . 9 0 4}$ & 0.059 & 0.250 & 0.064 \\
Mixture ratio & -0.138 & 0.357 & $\mathbf{0 . 8 7 3}$ & -0.094 \\
Age & 0.425 & 0.328 & -0.081 & $\mathbf{0 . 6 3 8}$ \\
Crown closure & -0.346 & $-\mathbf{0 . 6 3 6}$ & 0.378 & -0.483 \\
Average temperature & $\mathbf{0 . 9 3 7}$ & 0.159 & 0.068 & 0.166 \\
Maximum temperature & $\mathbf{0 . 9 5 5}$ & -0.206 & -0.013 & 0.104 \\
Sum of hot-days & $\mathbf{0 . 9 2 4}$ & -0.068 & 0.241 & -0.151 \\
Sum of summer-days & $\mathbf{0 . 9 7 4}$ & -0.126 & 0.047 & -0.047 \\
Precipitation sum & -0.122 & $\mathbf{0 . 9 3 4}$ & -0.022 & -0.014 \\
Precipitation sum between May-Aug. & -0.559 & $\mathbf{0 . 5 8 1}$ & 0.213 & 0.208 \\
Proportion of Kraft class 1/2 & 0.088 & $\mathbf{- 0 . 6 0 1}$ & 0.447 & 0.412 \\
\hline
\end{tabular}

The PCA detected three groups among the sample plots (Figure 1). These groups are colored red, yellow, and green. The red group contains the sample plots that had the strongest correlation between leaf loss and weather parameters according to CReMIT. The other plots in PCA also show an order similar to the results of CReMIT. 


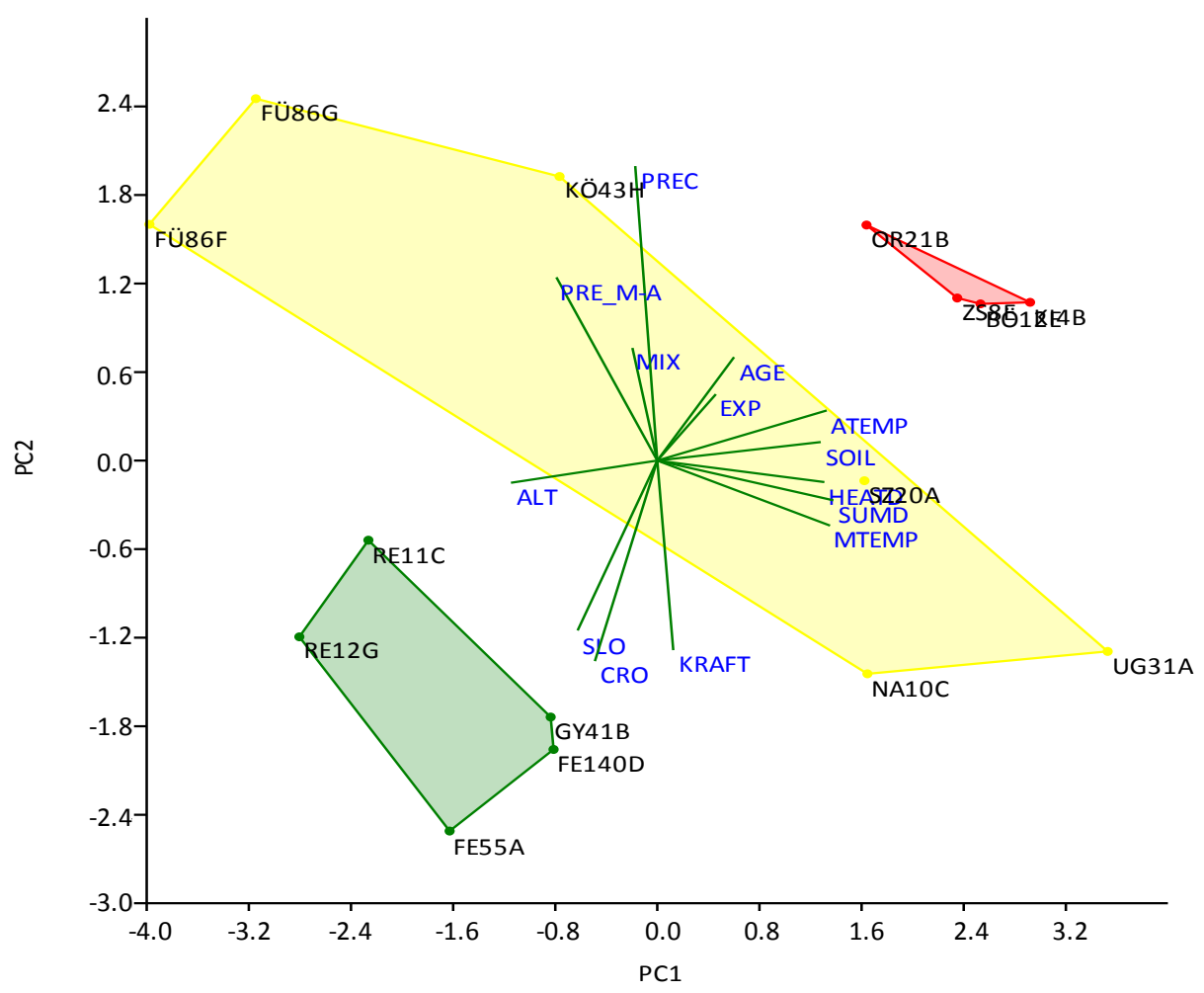

Figure 1. Scatter biplot of PCA. The diagram displays both the loadings (correlations between the original environmental variables and the components) as labelled vectors and the component scores of survey plots as labels and colored points. Survey plots with similar parameters are grouped together and linked with colored convex hulls. Plot names are abbreviated with the first 2 and the last 3 characters.

\section{DISCUSSION}

In this paper we processed a previously gathered dataset on beech health, and searched for statistically detectable correlations with weather indices (in an available meteorological dataset). Our methods successfully detected known connections and demonstrated that these methods are serviceable even in extremely complex systems. That temperature affects leaf loss much more than precipitation sum is an important result from a forest protection perspective. If higher mean temperatures do occur (as they have in recent years), neither the same amount nor a slightly higher amount of precipitation will prevent beech trees from declining. We also could statistically support that beech forests in less suitable climatic conditions are more susceptible to weather extremities.

More specifically, most of the results supported our preliminary hypotheses: temperature and precipitation-type weather parameters have a consequential effect on beech health. Both of the used statistical methods supported these presumptions.

As we assumed, the CReMIT method resulted in a relatively low number of significant correlations. Since forest ecosystems are extremely complex, we could not expect simple linear correlations, as mentioned by Berki et al. (2014). Detecting statistical patterns in forests is often difficult (Granier et al. 1999). Even so, significant results could be detected with weather parameters two years before the actual leaf loss. Time windows in the damage year gave the strongest significant results. Additionally, as was the case in our work, studies examining the weather dependence of beech growth with different running window statistical methods also 
detected correlations with various drought indexes (Manninger et al. 2011, Garamszegi - Kern 2014).

Monthly maximum temperature showed frequent and remarkable positive correlations with leaf loss, which is similar to conclusions many researchers have reached regarding average temperature (Siedling 2007, Zimmermann et al. 2015, Popa et al. 2017). In our analysis, this effect could even be detected with temperature values two years before the actual leaf loss. The number of hot days had a high significance in some cases, but the lower occurrence made patterns undetectable.

In our results, the effect of monthly precipitation sums on beech health was weaker than the effect of monthly maximum temperature. As expected, precipitation sums showed mostly negative correlations with leaf loss in our results. Precipitation sum values from previous years had some significant correlations on some time windows, as expected, but the actual year had the greatest effect (in particular sample plots most time windows had significant correlations) on the health status. These findings coincide with results of previous European studies, namely that higher amounts of precipitation have a positive effect on beech health (Meier - Lauschner 2008a, Seletković et al. 2009, Delaporte et al. 2016).

Although our input datasets were not optional (we had to use the available data from our sample plots), the weaker effects of precipitation compared to temperature and the unexpected correlations may raise a potential methodological issue: Using non-locally measured data (10x10 km grid interpolation in our case) may not be reliable enough to reveal the real correlations because the spatial variation of precipitation is very high (Manninger 2017). This may, at least partly, explain the controversial correlations. For every meteorological index, we detected that nearly the same plots had stronger correlations, while other plots had no responses or weak significant responses. The four plots showing the strongest responses kept this feature in almost every parameter and in both Kraft classes.

Sample plots situated in less favorable sites showed consistently stronger correlations with weather parameters. In fact, the plots are all situated in areas where the climate had become suboptimal for beech stands. According to Gálos and Führer (2018), this even applies to beech stands established from 1971-2010. The weather extremes in suitable sites affect health status less intensively. Although our plots are not situated on an ideal altitude for beech, many sample plots may remain relatively healthy. On the lower edge of the climate belt suitable for beech, the health statuses were generally worse.

It is known that many forest stand and forest site parameters impact beech health; for example: stands with higher canopy closure are less susceptible to health problems than those with low canopy closure (Csóka et al. 2009; Bošel'a et al. 2016). Mixed stands also appear to be more resistant and resilient than artificially grown monoculture beech forests (Mölder Leuschner 2014, Metz et al. 2016). Nevertheless, seedlings and young trees in mixed forests are still vulnerable to extreme droughts (Lübbe et al. 2015).

PCA detected site and stand parameters, which allowed for the establishment of three identifiable groups among the plots. We could conclude that the differences in the correlations between forest health and weather indices (CReMIT results) in the different sample plots show the same variances, which can be obtained by the PCA examination of climate, forest stand, and site data. This fact implies that differences are caused by these climatic, site, and stand parameters. The importance ranking of these parameters on beech health in our results is monthly maximum temperature, altitude, topsoil layer thickness, monthly precipitation sum, tree social class, canopy closure, slope, species mixture, stand age, and exposure. The patterns of PCA and CReMIT results among the sample plots are almost identical, so the statistical variances caused by leaf loss and site parameters are also almost identical. This implies that the weather effect on beech health is influenced by forest stand and site parameters. Additionally, 
it is influenced in the manner PCA calculated (Table 3). This also suggests that beech health risks can be projected based on forest site and stand data.

These results support earlier findings (Neirynck - Roskams 1999, Stribley - Ashmore 2002, Siedling 2007, Seletković et al. 2009). According to Potočić et al. (2008), during years without weather extremes, the correlation between weather and leaf loss is not particularly remarkable, but a strong connection can be detected in extremely droughty years when the correlation between leaf loss and temperature appears much stronger. Popa et al. (2017) also found different responses of beech health to the weather parameters. In areas where beech occurs naturally, temperature increase has a positive effect on the health status. Wherever beech grows outside this area, precipitation has a moderately positive effect on health, while temperature increase has a negative effect. On the upper edge of the beech area (in high mountains), temperature had a clearly positive effect. On optimal forest sites for beech, both temperature and precipitation had little effect on tree health (Popa et al. 2017). These findings are the logical results of the process of forest acclimatization to weather: the variability of environmental parameters in the long term established a natural range of a certain species that have low impact influence in the "core area". On the margins, these parameters either open a new frontier for the species, or reduce the area of the species.

Tree-ring analyses provided similar results and correlations between ring width and early summer temperatures than with late summer precipitations in Central Europe. With lower altitudes - which regularly means worsening climate for beech - the effects become stronger (Kolář et al. 2017).

There are many ways to improve the research of weather and forest health relationships. Permanent "on the spot" meteorological parameter measurements would be a major step forward. Applying health indicators other than leaf loss (i.e. measuring photosynthetic activity, sap flow, etc.) could also be a way forward.

Some weather parameters - those not included in our study - could also modify health responses. Cloudy weather (occurring often in mountain valleys) can greatly decrease leaf transpiration (Rozas et al. 2015). Air humidity can also be an important factor. Furthermore, the quantity of soil nitrogen can exacerbate the effects of drought (Dziedek et al. 2016). Measuring these parameters in the future would be extremely useful for understanding beech health responses.

Individual tree level differences in sensitivity and response are also considerable since intraspecific/intrapopulation diversity (i.e. phenological cycle) is typical in all populations and biological processes (Delpierre et al. 2017).

It would be very useful to forecast beech damage - possibly similarly to Italian researchers who found a fungal pathogen's presence or absence (Biscogniauxia nummularia) to be a suitable sign for indicating drought damage in Mediterranean areas (Luchi 2015).

Some opinions suggest that the southern provenances should be more adapted and, therefore, more resistant to a warmer and drier climate (Cavin - Jump 2016, Horváth - Mátyás 2016). Others believe this type of adaptation potential is not strong enough in the case of beech (Knutzen et al. 2015), or that genetic diversity affects the shoot and the leaf growth more than the root growth, which is crucial from a drought tolerance perspective (Meier - Leuschner 2008b).

The predictive site choice of a given tree species (or the tree species choice for a given site) is increasingly important. The climate tolerance of different tree species must be carefully considered since this significantly influences the stability of future forests (Hlásny et al. 2017).

Moreover, if climate change proceeds in the manner some projections predict, more frequent and severe damage events will occur. These events will be far more connected to weather conditions than they currently are (Gálos - Führer 2018). Clearly, a proactive sylviculture involving mixed 
beech stands, increased structural diversity, and high canopy closure (avoiding large cutting areas) may considerably reduce the risks imposed by the changing climate.

Acknowledgements: We would like thank Balázs Nyul, Ervin Rasztovits, Ernő Führer, Anikó Jagodics, and Levente Szőcs for their help and advice.

\section{REFERENCES}

Arend, M. - SeVer, K. - Pflug, E. - Gessler, A. - Schaub, M. (2016): Seasonal photosynthetic response of European beech to severe summer drought: limitation, recovery and post-drought stimulation. Agricultural and Forest Meteorology 220: 83-89.

https://doi.org/10.1016/j.agrformet.2016.01.011

ASSMANN, E. (1968): Nauka o produkcyjności lasu. [The forest productivity], Pwril, Warsaw. (in Polish)

Augustaitis, A. - Kliučius, A. - Marozas, V. - Pilkauskas, M. - Augustaitiene, I. - Vitas, A. - STASZEWSKI, T. - JANSONS, A. - DREIMANIS, A. (2015): Sensitivity of European beech trees to unfavorable environmental factors on the edge and outside of their distribution range in northeastern Europe. iForest 9 (2): 259-269. https://doi.org/10.3832/ifor1398-008

BERKI, I. - MÓRICZ, N. - RASZTOVITS, E. - VIG, P. (2007): A bükk szárazság tolerancia határának meghatározása. [Determining the aridity-tolerance boundary of beech.] In: Mátyás Cs. - Vig P. (eds): Erdő és klíma V. Nyugat-Magyarországi Egyetem, Sopron, 213-228. (in Hungarian)

BOŠEL'A, M. - ŠTEFANČÍK I. - PETRÁŠ R. - VACEK S. (2016): The effects of climate warming on the growth of European beech forests depend critically on thinning strategy and site productivity. Agricultural and Forest Meteorology 222: 21-31. https://doi.org/10.1016/j.agrformet.2016.03.005

CAVIN, L. - JUMP, A. S. (2017): Highest drought sensitivity and lowest resistance to growth suppression are found in the range core of the tree Fagus sylvatica L. not the equatorial range edge. Global Change Biology 23: 362-379. https://doi.org/10.1111/gcb.13366

CsÓKA, GY. - KOLTAY, A. - HIRKA, A. - JANIK, G. (2009): Az aszályosság hatása kocsánytalan tölgyesek és bükkösök egészségi állapotára. [The effect of drought on pedunculate oak and beech forests.] 'Klíma-21' Füzetek 57: 64-73. (In Hungarian)

Del Río, S. - Álvarez-Esteban, R. - CANo, E. - Pinto-Gomes, C. - Penas, Á. (2018): Potential impacts of climate change on habitat suitability of Fagus sylvatica L. forests in Spain. Plant Biosystems 152 (6): 1205-1213. https://doi.org/10.1080/11263504.2018.1435572

DElaporte, A. - BAZOT, S. - DAMESIN, C. (2016): Reduced stem growth, but no reserve depletion or hydraulic impairment in beech suffering from long-term decline. Trees 30 (1): 265-279. https://doi.org/10.1007/s00468-015-1299-8

DelPierRe, N.-Guillemot, J.- DufrÊNe, E.- CECChini, S. - Nicolas, M. (2017): Tree phenological ranks repeat from year to year and correlate with growth in temperate deciduous forests. Agricultural and Forest Meteorology 234-235: 1-10. https://doi.org/10.1016/j.agrformet.2016.12.008

DZIEDEK, C. - OHEIMB, G. VON, CALVO, L. - FichtNer, A. - KRIEBITZSCH, W.-U. - MARCOS, E. - PitZ, W. T. - HÄRDTLE, W. (2016): Does excess nitrogen supply increase the drought sensitivity of European beech (Fagus sylvatica L.) seedlings? Plant Ecololgy 217 (4): 393-405. https://doi.org/10.1007/s11258-016-0581-1

FÜHRER E. - HORVÁTH L. - JAGODICS A. - MACHON A. - SZABADOS I. (2011): Application of a new aridity index in Hungarian forestry practice. Időjárás 115 (3): 205-216.

FÜHRER, E. - MAROSI, GY. - JAGODICS, A. - JUHÁSZ, I. (2011): A klímaváltozás egy lehetséges hatása az erdőgazdálkodásban. [A possible effect of climate change in forest management.] Erdészettudományi Közlemények 1 (1): 17-28. (in Hungarian)

GÁLOS B. - FÜHRER E. (2018): A klíma erdészeti célú előrevetítése. Erdészettudományi Közlemények 8 (1): 43-55. https://doi.org/10.17164/EK.2018.003

GARAMSZEGI, B. - KERN, Z. (2014): Climate influence on radial growth of Fagus sylvatica growing near the edge of its distribution in Bükk Mts., Hungary. Dendrobiology 72: 93-102. https://doi.org/10.12657/denbio.072.008 
Geßler, A. - Keitel, C. - Kreuzwieser, J. - MatysseK, R. - Seiler, W. - Rennenberg, H. (2007): Potential risks for European beech (Fagus sylvatica L.) in a changing climate. Trees 21: 1-11. https://doi.org/10.1007/s00468-006-0107-X

GiAGLI, K. - GRIČAR, J. - VAVRČíK, H. - MENŠíK, L. - GRYC, V. (2016): The effects of drought on wood formation in Fagus sylvatica during two contrasting years. IAWA Journal 37 (2): 332-348. https://doi.org/10.1163/22941932-20160137

GRANIER, A. - BRÉDA, N. - BIRON, P. - VILLETTE, S. (1999): A lumped water balance model to evaluate duration and intensity of drought constraints in forest stands. Ecol. Model. 116: 269-283. https://doi.org/10.1016/S0304-3800(98)00205-1

HAMMER, Ø. - HARPER, D. A.T. - PAUL D. R. (2001): PAST: Paleontological Statistics Software Package for Education and Data Analysis. Palaeontologia Electronica, vol. 4, issue 1, art. 4: 9pp., 178kb. http://palaeo-electronica.org/2001_1/past/issue1_01.htm Accessed: 2020.10.10.

HoRVÁTH, A. - MÁTYÁs, Cs. (2016): The decline of vitality caused by increasing drought in a beech provenance trial predicted by juvenile growth. South-east European Forestry 7 (1): 21-28. https://doi.org/10.15177/seefor.16-06

HLÁSNY, T. - TROMBiK, J. - BoŠELA, M. - MERganič, J. - MARUŠÁK, R. - ŠEBeŇ, V. - ŠTĚPÁNeK, P. - KUBIŠTA, J. - TRNKAD, M. (2017): Climatic drivers of forest productivity in Central Europe. Agricultural and Forest Meteorology 234-235: 258-273.

https://doi.org/10.1016/j.agrformet.2016.12.024

ICP Forest Manual Part IV.: Visual assessment of crown condition and damaging agents. http://icpforests.net/page/icp-forests-manual Accessed: 2020.04.21.

JANIK, G. - HIRKA, A. - KOLTAY, A. - JUHÁSZ, J.- CSÓKA, GY (2016): 50 év biotikus kárai a magyar bükkösökben. [50 years biotic damage in the Hungarian beech forests.] Erdészettudományi Közlemények 6 (1): 45-60. (in Hungarian) https://doi.org/10.17164/EK.2016.005

JuMP, A. S. - HunT, J. M. - PEÑUELAS, J. (2006): Rapid climate change-related growth decline at the southern range edge of Fagus sylvatica. Global Change Biology 12: 2163-2174. https://doi.org/10.1111/j.1365-2486.2006.01250.x

KNUTZEN, F. - MEIER, I. C. - LEUSCHNER, C. (2015): Does reduced precipitation trigger physiological and morphological drought adaptations in European beech (Fagus sylvatica L.)? Comparing provenances across a precipitation gradient. Tree Physiology 35 (9): 949-963. https://doi.org/10.1093/treephys/tpv057

KolÁŘ, T. - ČERMÁK, P. - TRNKA, M. - ŽID, T. - RYBNíČEK, M. (2017): Temporal changes in the climate sensitivity of Norway spruce and European beech along an elevation gradient in Central Europe. Agricultural and Forest Meteorology 239: 24-33. https://doi.org/10.1016/j.agrformet.2017.02.028

KolTAY, A. (2004): Erdővédelmi monitoring rendszerek Magyarországon. [Monitoring systems in forest protection in Hungary.] Erdészeti Lapok 139 (9): 270-272. (in Hungarian)

KRAFT, G. (1884): Beiträge ur Lehre von den Durch Forstungen. Schlagstellungen und Lichtungshieben, Hanover (cited by Oliver and Larson 1996).

LAKATOS, F. - MOLNÁR, M. (2009): Mass mortality of beech (Fagus sylvatica L.) in south-west Hungary. Acta Silvatica et Lignaria Hungarica 5: 75-82.

LÜBBe, T. - SCHuldT, B. - LeusChNER, C. (2015): Species identity and neighbor size surpass the impact of tree species diversity on productivity in experimental broad-leaved tree sapling assemblages under dry and moist conditions. Frontiers in Plant Science 6: 857. https://doi.org/10.3389/fpls.2015.00857

LuChi, N. - CAPRETTI, P. - FEduCCI, M. - VAnNini, A. - CeCCARelli, B. - VetTraino, A. M. (2015): Latent infection of Biscogniauxia nummularia in Fagus sylvatica: a possible bioindicator of beech health conditions. iForest - Biogeosciences and Forestry 9 (1): e1-e6. https://doi.org/10.3832/ifor1436-008

MANNINGER M. (2017): A csapadék változatosságának vizsgálata. [Investigation of the variation of precipitation.] Erdészettudományi Közlemények 7 (2): 99-113. (in Hungarian) https://dx.doi.org/10.17164/EK.2017.007

MANNINGER, M., - EDELÉNYI, M. - PÖDÖR, Z. - JEREB, L. (2011): Alkalmazott elemzési módszerek a környezeti tényezök fák növekedésére gyakorolt hatásának vizsgálatában. [Applied analytical 
methods in the examination of the effects of environmental factors on the growth of trees.] Erdészettudományi Közlemények 1 (1): 59-70. (in Hungarian)

MÁTYÁs, Cs. - BERKI, I. - CzÚCZ, B. - GÁlos, B. - MóRICZ, N. - RASZTOVITS, E. (2010): Future of beech in southeast Europe from the perspective of evolutionary ecology. Acta Silvatica et Lignaria Hungarica (6): 91-110.

MeIER, I. C. - LeUSCHNER, C. (2008a): Leaf Size and Leaf Area Index in Fagus sylvatica Forests: competing effects of precipitation, temperature and nitrogen availability. Ecosystems 11: 655-669 https://doi.org/10.1007/s10021-008-9135-2

MEIER, I. C. - LEUSCHNER, C. (2008b): Genotypic variation and phenotypic plasticity in the drought response of fine roots of European beech. Tree Physiology 28: 297-309. https://doi.org/10.1093/treephys/28.2.297

MetZ, J. - ANNighÖFER, P. - SCHAll, P. - ZimmermanN, J. - KAHL, T. - SCHUlZE, E.-D. - AMMER, C. (2016): Site-adapted admixed tree species reduce drought susceptibility of mature European beech. Global Change Biology 22 (2): 903-920. https://doi.org/10.1111/gcb.13113

Michel, A. - SEIDLING, W. (eds.) (2014): Forest Condition in Europe: 2014 Technical Report of ICP Forests. Report under the UNECE Convention on Long - Range Transboundary Air Pollution (CLRTAP). Vienna: BFW Austrian Research Centre for Forests. BFW - Dokumentation 18/2014. 164 p. ISBN 978-3-902762-38-2. ISSN 1811-3044.

MÖLDER, I. - LEUSCHNER, C. (2014): European beech grows better and is less drought sensitive in mixed than in pure stands: tree neighbourhood effects on radial increment. Trees 28 (3): 777-792. https://doi.org/10.1007/s00468-014-0991-4

NEIRYNCK, J. - ROSKAMS, P. (1999): Relationships between crown condition of beech (Fagus sylvatica L.) and throughfall chemistry. Water, Air, \& Soil Pollution 116/1-2: 389-394. https://doi.org/10.1023/A:1005246807137

NFK (2020): Magyarország erdeivel kapcsolatos adatok [Data of forests in Hungary] http://www.nfk.gov.hu Accessed: 2020.04.21. (in Hungarian)

PEARSON, K. (1901). "On lines and planes of closest fit to systems of points in space". Philosophical Magazine 2 (11): 559-572. https://doi.org/10.1080/14786440109462720.

PÖDÖR, Z. - EDELÉNYI, M. - JEREB, L. (2014): Systematic Analysis of Time Series - CReMIT. Infocommunication Journal VI (1): 16-22.

POPA, I. - BADEA, O. - SILAGHI, D. (2017): Influence of climate on tree health evaluated by defoliation in the ICP level I network (Romania). iForest 10: 554-560. https://doi.org/10.3832/ifor2202-009

RASZTovits E. - Berki I. - MÁTYÁs Cs. - CZIMBER K. - PötZelsberger E. - MóRICZ N. (2014): The incorporation of ex-treme drought events improves models for beech persistence at its distribution limit. Annals of Forest Science 71: 201-210. https://doi.org/10.1007/s13595-013-0346-0

Rozas, V. - CAMARERO, J. J. - SANGÜESA-BARREDA, G. - Souto, M. - GARCÍA-GonZÁLEZ, I. (2015): Summer drought and ENSO-related cloudiness distinctly drive Fagus sylvatica growth near the species rear-edge in northern Spain. Agricultural and Forest Meteorology 201:153-164. https://doi.org/10.1016/j.agrformet.2014.11.012

SIEDLING, W. (2007): Signals of summer drought in crown condition data from the German Level I network. Eur. J. Forest. Res. 126 (4): 529-544. https://doi.org/10.1007/s10342-007-0174-6

STRIBLEY, G. H. - ASHMORE, M. R. (2002): Quantitative changes in twig growth pattern of young woodland beech (Fagus sylvatica L.) in relation to climate and ozone pollution over 10 years. Forest Ecol. Manag. 157: 191-204. https://doi.org/10.1016/S0378-1127(00)00665-4

SZENTIMREY, T. - BiHARI, Z. - SZALAI, S. (2005): Meteorological Interpolation based on Surface Homogenized Data Basis (MISH). Geophysical Research Abstracts, Vol. 7, 07310, 2005 SRef-ID: 1607-7962/gra/EGU05-A-07310

ZimmermanN, J. - HAUCK, M. - DUlAMSUREN, C. - LeusChNER, C. (2015): Climate warming-related growth decline affects Fagus sylvatica, but not other broadleaved tree species in Central european mixed forests. Ecosystems 18 (4): 560-572. https://doi.org/10.1007/s10021-015-9849-x 